\title{
ASPECTOS FUNDAMENTAIS DA CONSTITUIÇÃO DE 1988
}

\author{
Manoel Gonçalves Ferreira Filho \\ Professor Titular de Direito Constitucional \\ do Departamento de Direito Público da FDUSP \\ Doutor em Direito pela Universidade de Paris
}

Resumo:

$\mathrm{O}$ artigo analisa preliminarmente as características gerais da Constituição de 1988, comparando-a às constituições de tipo clássico, tais como a constituição-garantia, a constituição-balanço e a constituiçãodirigente, da qual a nossa se aproxima.

Em seguida aborda a questão das normas não-auto-executáveis e de sua complementação por meio de comando judicial, questão relevante em uma Constituição como a nossa. Recorda a lição recente do mestre português Jorge Miranda e a distinção por ele feita entre "normas exeqüíveis por si mesmas", "normas preceptivas não exequíveis por si mesmas" e "normas programáticas" No que concerne às normas não exeqüíveis de imediato discute suas quatro espécies: normas programáticas, de estruturação, incompletas propriamente ditas e normas condicionadas.

Passa a discutir, na seqüência, a questão do sistema de governo, da opção presidencialismo versus parlamentarismo, fazendo um breve histórico do assunto, passando então a uma análise do processo constituinte e de como a nossa Constituição resolve esta questão, encerrando este tópico com a análise do poder do presidente.

Aborda, então, a Ordem Econômica na Constituição, com os temas "Tipos de Organização Econômica", da delimitação entre o campo de iniciativa privada e da pública, da determinação do regime jurídico dos fatores de produção e da definição da finalidade e dos princípios gerais da vida econômica.

Finaliza com o balanço dos resultados práticos da implantação da nova Constituição, além de uma abordagem conjuntural da crise político-institucional por que passa o país.

Abstract:

The article analyzes first the general features of the Constitution of 1988, comparing it to constitutions of the classical type, such as the warranty-constitution, the balance-constitution and the directing-constitution, that is near to ours.

It broaches then the questions of non-self-executable rules and their complementation by means of judicial command, a question of relevance in a constitution such as ours. It reminds us of the recent lesson 
of the portuguese master Jorge de Miranda and the distinction made by him between "self-executable rules", "preceptoral non-self-executable rules" and "program rules" It discusses the four kinds of non-immediately-selfexecutable rules: program rules, structure rules, strictly speaking incomplete rules and conditioned rules.

It goes on to discuss the questions of system of government, of the option of president vs parliament, going into a brief history of the subject and making an analysis of the process of making the constitution and of how our constitution solves the question and finishing the subject with an analysis of the power of the president.

It broaches then the Economical Order of the Constitution with the themes "Types of Economical Organization", of the boundaries between private and public enterprise, of the determination of the juridical regime of the production factors and the definition of the end and general principles of economical life.

The article ends with the balance of the practical results of the implantation of the new Constitution, and an analysis of the conjuncture of the political and institutional crisis the country is going through.

1. Há praticamente quatro anos, ou seja, a 5 de outubro de 1988, entrou em vigor a nova Constituição brasileira.

Ainda não houve, por isso, o tempo indispensável para que a doutrina cristalizasse a interpretação quanto a numerosas regras; muito menos, para que os tribunais definissem a jurisprudência a respeito delas. Basta lembrar, para comprová-lo, que nenhum jurista conseguiu até agora completar livro de comentários a seu texto; da mesma forma que o Supremo Tribunal Federal ainda não logrou enfrentar senão um número ínfimo das questões constitucionais a ele submetidas. Assim, é forçosamente com muita cautela e humildade que se deve proceder na sua análise.

O presente trabalho não visa, em conseqüência, mais que desempenhar o papel de uma introdução ao estudo da Constituição brasileira de 1988, de caráter essencialmente informativo. Para tanto, cinge-se a alguns aspectos ou pontos fundamentais. $\mathrm{O}$ primeiro concerne às características gerais da Constituição, as quais a definem como integrante do tipo constituiçãodirigente; o segundo, ao tema político de maior relevo, o sistema de governo, o presidencialismo; o último aborda a matéria mais discutida na Constituinte, a questão da ordem econômica, a "constituição econômica", que nela se contém. 
Enfim, como fecho do trabalho, apontar-se-ão algumas poucas inferências que se podem extrair da prática, até agora, da nova Constituição.

\section{Características gerais.}

2.

A Constituição brasileira de 1988 oferece, desde a primeira vista, uma peculiaridade que a distingue das anteriores: ela se preocupa, e em pormenores, com assuntos que não eram regulados, mas, no máximo, mencionados, nas constituições precedentes. Assim, possui ela, por exemplo, capítulos sobre a Política Urbana, sobre o Sistema Financeiro Nacional, sobre a Seguridade Social, compreendendo seções referentes à Saúde, à Previdência Social, à Assistência Social, sobre a Educação, a Cultura e o Desporto, sobre a Ciência e a Tecnologia, sobre a Comunicação Social, sobre o Meio Ambiente, sobre a Familia, a Criança, o Adolescente e o Idoso, sobre o Índio, etc.

Ao tratar destas questões, ademais, ela formula definições (como a de patrimônio cultural, art. 216, que dá bem a medida de seu estilo: "Constituem patrimônio cultural brasileiro os bens de natureza material e imaterial, tomados individualmente ou em conjunto, portadores de referência à identidade, à ação, à memória dos diferentes grupos formadores da sociedade brasileira"...), juridicamente irrelevantes (e substancialmente discutíveis). Outrossim, esboça planos e programas de transformação da realidade presente (Saúde, art. 196; Educação, art. 208; Ciência e Tecnologia, art. 218; etc.).

Assim, quem a compara às constituições brasileiras anteriores, ou às constituições de tipo clássico, logo se apercebe de que ela segue um outro modelo e se insere noutro tipo.

3. O tipo clássico de Constituição a constituição "escrita" nascido no século XVIII, tem uma finalidade definida: garantir os direitos naturais do Homem (vida, liberdade, segurança, propriedade). Daí poder-se chamá-lo de constituição-garantia.

Este tipo de constituição procura atingir a sua finalidade, estabelecendo uma organização limitativa do Poder. O seu modelo foi traçado no art. 16 da Declaração dos Direitos do Homem e do Cidadão: 'A sociedade na qual não é assegurada a garantia dos direitos, nem determinada a separação dos poderes, nāo tem constituição" 
4. Observe-se ainda que o tipo clássico de Constituição não se preocupa senão com o Poder político, almejando impedir-lhe os abusos. Ele não cuida de outras formas de opressão de natureza não-política.

É verdade que, após a Primeira Guerra Mundial, a Constituição alemã de 11 de agosto de 1919 (pois a do México de 1917 não teve na época maior repercussão) estabeleceu um novo modelo. Este estende a tutela da Constituição aos planos político e social. Reconhece direitos econômicos e sociais do indivíduo e dos grupos, como o direito ao trabalho, o direito à educação, o direito de greve, etc. Não se perde, todavia, a perspectiva garantista. As constituições do novo modelo, muitas ainda em vigor como a da Itália de 1948, a Lei Fundamental da República Federal Alemã de 1949, ainda visam, em última instância, a garantir os direitos fundamentais do ser humano. Continuam, portanto, constituições-garantia.

5. A este tipo clássico os juristas soviéticos contrapuseram o da constituição-balanço.

Foi Lassalle quem, por primeiro, contrapôs a constituição "real" à constituição "escrita". Aquela é "composta pelos fatores reais e efetivos que regem a sociedade"; esta é ... uma "folha de papel". 1

Ora, essa colocação se ajusta perfeitamente ao determinismo histórico que formula o marxismo. Daí a adoção da idéia de que toda constituição é o reflexo ou o balanço do quadro prevalecente num determinado momento ou etapa histórica, posição esta tomada como dogma no período estalinista.

Realmente, ao ser elaborada a Constituição soviética de 1936, Stalin expôs esse entendimento em texto bem conhecido dos constitucionalistas: "Ao estabelecer o projeto de nova Constituição, a Comissão de Constituição partia do princípio de que uma constituição não deve ser confundida com um programa. Isto significa que entre um programa e uma constituiçāo existe uma diferença essencial. Enquanto um programa fala do que não é ainda e do que deve ser ainda obtido e conquistado no futuro, a Constituição, ao contrário, deve falar do que já

1. Ferdinand Lassalle, $O$ que é uma Constituição política (trad. port.), São Paulo, Global, 1987, p. 47. 
foi obtido e conquistado, agora, no presente. O programa concerne principalmente ao futuro, à constituição, ao presente... de modo que o projeto da nova Constituição representa o balanço do caminho percorrido, o balanço das conquistas já adquiridas. É, em conseqüência, o registro e a consagração legislativa do que já foi obtido e conquistado de fato". ${ }^{2}$

Por essa razão, os constitucionalistas soviéticos ensinam que a Constituição de 1924 corresponde à etapa da "ditadura do proletariado"; a de 1936, à do Estado "socialista de operários e camponeses"; a de 1977, à do Estado do "povo inteiro". 3

Esta última, com as emendas de 1988, se tornou a Constituição da "perestroika", ${ }^{4}$ cabendo-lhe presidir aos últimos dias do sistema soviético.

6. Nos últimos vinte anos, vem-se desenvolvendo uma nova maneira de conceber a Constituição. É a idéia da constituição-dirigente para usar da expressão cunhada por Canotilho, o principal divulgador do modelo nos países de língua portuguesa. ${ }^{5}$ A Constituição portuguesa, na versão promulgada em 1976, é o seu principal exemplo.

Nesta concepção, a Constituição é mais do que organização do Poder, é um programa de conformação da sociedade. Destarte, aponta fins, traça planos e programas destinados a alcançá-los. Tem caráter prescritivo e é exatamente por meio de prescrições que pretende dirigir a atuação governamental. Ela, como Lei Suprema, definiria "uma direção política permanente", que se imporia aos governos constituídos de acordo com suas regras, portanto, sobre qualquer "direção política do governo", naturalmente "uma direção política contingente".

2. Apud Jean-Guy Collignon, La théorie de l'État du peuple tout entier en Union Soviétique, Paris, P.U.F., 1967, p. 5.

3. Ibid., p. 17.

4. Deve-se observar, todavia, que as emendas de 1988 instituíram, ainda que de modo precário, um controle de constitucionalidade na Uniāo Soviética. Isto equivale a trazer a Constituição para o plano do dever-ser, o que importa em abandono da concepção constituiçāobalanço.

5. Joaquim Gomes Canotilho, Constituição-dirigente e vinculação do legislador, Coimbra, Coimbra, 1982. 
Isto significa que a Constituição se torna, acima de tudo, uma "lei material" a preordenar fins, objetivos e até meios, num sentido rigidamente definido. Deixa de ser u'a mera "lei processual", um "instrument of government", a estabelecer competências, a regular procedimentos e fixar limites.

A esta "lei material" está vinculada a atuação governamental, que, não a efetivando, incorre em inconstitucionalidade por omissão. E poderá ser o governo obrigado judicialmente a efetivar as promessas constitucionais, por meio de novos remédios, como a ação de inconstitucionalidade por omissão, que prevê o art. 283 da Constituição portuguesa (versão de 1982).

A constituição-dirigente tem ambição globalizante: política, econômica e social. Nada lhe é estranho.

$\mathrm{Na}$ verdade, a inspiração de Canotilho e de outros partidários da concepção é neomarxista. Entretanto, não está nisto um traço essencial, mas sim acessório. De qualquer modo, toda constituição-dirigente é constituição política, econômica e social, pretendendo operar profundas transformações da realidade, em todos estes planos.

7. A Constituição brasileira de 1988 resultou, em grande parte, do propósito de estabelecer uma lei fundamental voltada para reformas econômicas e sociais.

Isto transparece do fato de que, antes da convocação da Assembléia Constituinte, que iria formular a nova Lei Magna, já se haviam feito as reformas políticas e institucionais destinadas a "varrer o entulho autoritário". Com efeito, a Emenda n. 25, de 15 de maio de 1985, fez a reforma política: estabeleceu a eleição presidencial direta, facilitou a criação de partidos, aboliu a fidelidade partidária, eliminou o decurso de prazo para a aprovação de projetos de lei ou decretos-leis de autoria do Executivo, etc. E, quem comparar a ordem política estabelecida na Constituição em decorrência de suas disposições, com a que consagrou a Constituição de 1988, reconhecerá que são praticamente idênticas.

Assim, a Constituinte, convocada pela Emenda n. 26, de 27 de novembro de 1985, tinha como tarefa, velada, conquanto conhecida de todos, programar reformas sociais e econômicas tidas como indispensáveis e urgentes. ${ }^{6}$

6. V. a esse respeito o meu livro $O$ Poder Constituinte, $2^{a}$ ed., São Paulo, Saraiva, 1985, n. 139. 
8. Este propósito, quase unanimemente adotado pelos constituintes, foi aproveitado para que se impusesse como modelo a Constituição portuguesa de 1976. Isto levou à adoção do tipo constituição-dirigente para o texto afinal aprovado.

Assinala-o José Afonso da Silva: "Assumiu o novo texto a característica de constituição-dirigente, enquanto define fins e programa de ação futura, menos no sentido socialista do que no de uma orientação social democrática, imperfeita, reconheça-se" ${ }^{\prime}{ }^{7}$

Não tem ele, de fato, caráter socializante. Tinha-o o projeto; entretanto, emendas a ele opostas pelo chamado Centrão e aprovadas pelo Plenário eliminaram esse caráter, embora deixassem presente uma ênfase reformadora, de índole social.

É, porém, incontestavelmente, de intenção globalizante, abarcando não só o político mas também o econômico e o social.

Contém numerosos planos e programas, segundo se apontou, portanto, numerosas normas programáticas, não-auto-executáveis, cuja futura efetivação se confiou, inclusive, a mecanismos judiciais como a ação de inconstitucionalidade por omissão e o mandado de injunção. Aquela é disciplinada no art. 103, $\S 2^{2}$, que lhe define o alcance: "Declarada (pelo Supremo Tribunal Federal) a inconstitucionalidade por omissāo de medida para tornar efetiva norma constitucional, será dada ciência ao Poder competente para a adoção das providências necessárias e, em se tratando de órgão administrativo, para fazê-lo em trinta dias". Já sobre o mandado de injunção, dispõe o art. 5\%, LXXI: "Conceder-se-á mandado de injunção sempre que a falta de norma regulamentadora torne inviável o exercício dos direitos e liberdades constitucionais e das prerrogativas inerentes à nacionalidade, à soberania e à cidadania"

Este último ponto, que envolve a problemática das normas nãoauto-executáveis e de sua complementação por meio de comando judicial, é de tal relevo numa constituição-dirigente, portanto, na Constituição brasileira, que merece um aprofundamento. 
9. A aplicabilidade imediata das normas constitucionais é conclusão de há muito aceita pela doutrina.

Entretanto, como já apontou Thomas Cooley, no Treatise on constitutional limitations, ${ }^{8}$ cuja doutrina Rui Barbosa incorporou ao pensamento jurídico brasileiro, ${ }^{9}$ há normas constitucionais que não podem ser de imediato aplicadas, porque são incompletas. São "not-self-executing provisions", que Rui traduziu por "normas não-auto-executáveis", que se opõem às regras completas, portanto, imediatamente aplicáveis, "self-executing provisions", "normas autoexecutáveis".

Estas últimas normas compreendem aquelas que indicam princípios, apontam metas, traçam programas. Daí, muitos a elas se referirem como "normas programáticas", embora estas sejam apenas uma espécie dentre as normas não-auto-executáveis.

Com efeito, vale recordar a lição recente de Jorge Miranda. O mestre português contemporâneo assinala deverem-se distinguir entre "normas exeqüiveis por si mesmas", "normas preceptivas não-exeqüíveis por si mesmas" e "normas programáticas". As primeiras são auto-executáveis, porque completas em todos os seus elementos. As segundas, incompletas nalgum ponto, somente reclamam a complementação legislativa para tornarem-se executáveis. Quanto às "normas programáticas", elas exigem mais do que a mera complementação legal, pois, não dispensam para tornarem-se efetivas "providências administrativas e operações materiais", também. ${ }^{10}$

Note-se que esta distinção entre "normas não-exeqüíveis por si mesmas" e "normas programáticas" se ajusta à distinção feita, a propósito da inconstitucionalidade por omissão, ao art. $103, \S 2^{\varrho}$ da Constituição brasileira. Com efeito, se a falta é tão-somente de lei de complementação, o Tribunal dará "ciência" ao Poder competente, o Legislativo; contudo, se a falta é das

8. $6^{\text {a }}$ ed., Boston, 1890 , p. 99 e ss.

9. V. Comentários à Constituição Federal Brasileira, coligidos por Homero Pires, São Paulo, Saraiva, 1933, v. 2, p. 489 e ss.

10. Manual de direito constitucional, $2^{\mathrm{a}}$ ed., Coimbra, Coimbra, 1987, v. 2, p. 216 e ss. 
providências administrativas, ou de operações materiais, o Tribunal assinará o prazo de trinta dias para que o órgão competente as tome ou faça.

10. Na Constituição de 1988, a análise das numerosas normas nãoexeqüíveis de imediato sugere a existência de quatro espécies dentre elas:

a. Normas programáticas, no sentido dado à expressão por Jorge Miranda: normas que reclamam, além de regulamentação legal, providências administrativas ou materiais. Por exemplo, o direito à educação (art. 295) que reclama não só regulamentação mas também escolas, professores, etc.;

b. Normas de estruturação. Normas que prevêem órgãos mas deixam de estruturá-los, ou não o fazem senão parcialmente. Em ambos os casos, reclamam uma complementação legal. É o caso do Conselho da República, cuja organização e funcionamento depende de uma lei (ainda não editada), prevista no art. $90, \S 2^{2}$;

c. Normas incompletas propriamente ditas. São aquelas a que falta elemento imprescindível para que possam ser aplicadas. Por exemplo, a do art. 203 que atribui à pessoa portadora de deficiência e ao idoso que não possua meios de prover à própria manutenção, um "benefício mensal", isto "conforme dispuser a lei", que obviamente terá de precisar as condições que a norma constitucional apenas indica genericamente; $\mathrm{e}$

d. Normas condicionadas. Estas são regras que, embora numa análise objetiva apareçam completas, portanto, imediatamente aplicáveis, não o podem ser, porque expressamente o texto constitucional condicionou sua eficácia a uma lei. Isto quer dizer que a eficácia da norma está condicionada a uma apreciação de oportunidade por parte do legislador. É o caso de disposições contidas, por exemplo, nos parágrafos do art. 192 sobre o sistema financeiro nacional, as quais seriam de imediato aplicáveis, se o todo não estivesse condicionado a uma lei a ser editada. Na verdade, politicamente falando, esta espécie de normas resulta do equilibrio de forças entre grupos, hostis ou favoráveis a uma idéia, que se conciliam, adiando uma medida até uma decisão futura (que poderá jamais ser tomada) do legislador.

11. Houve, logo que vigente a nova Constituição, quem não admitisse a existência de normas não-executáveis de imediato em seu texto. Apoiavam essa 
opinião na letra do art. 5o, $\S 1^{\text {o: }}$ " As normas definidoras dos direitos e garantias fundamentais têm aplicação imediata".

Evidentemente, porém, esta afirmação fere a natureza das coisas. Uma norma incompleta não pode tornar-se auto-executável por um mero fiat constitucional.

Ademais, a própria Constituição desmente essa aplicabilidade imediata de todas as suas regras, na medida em que prevê ação de inconstitucionalidade por omissão e mandado de injunção, exatamente para fazerem eficazes e efetivas prescrições que edita.

II. O sistema de governo.

12.

Uma das raras questões políticas que se debateram intensamente na Constituinte foi a opção presidencialismo versus parlamentarismo.

Desde a República, salvo em brevíssimo período (setembro de 1961 - janeiro de 1963), o sistema de governo adotado no Brasil é o presidencialista, por inspiração do sistema norte-americano. $O$ sistema, porém, não funciona aqui como lá: apresenta, por exemplo, uma evidente exacerbação do poder presidencial. Por isso, os seus críticos, especialmente de 1946 para cá, propõem como solução para males políticos que afligem o Brasil a adoção do sistema parlamentarista.

13. Convém lembrar que, durante o Segundo Império, certamente entre 1847 e 1889, quando se proclamou a República, viveu o Brasil um parlamentarismo.

A Carta de 1824, é certo, não o previa expressamente, mas não o faziam também as constituições européias da época. Sua índole seguramente se adequava ao sistema, cujas formas se seguiram a partir de 1847 quando se criou a Presidência do Conselho de Ministros. Assim, embora a Carta atribuísse ao Imperador o Poder Executivo além do Poder Moderador, ${ }^{11}$ este Poder Executivo

11. A Constituição do Império previa quatro Poderes: o Legislativo, o Executivo, o Judiciário e o Moderador. Este, adotado segundo o modelo de Benjamin Constant, era conferido ao Imperador "para que, incessantemente, vele sobre a manutenção da independência, equilíbrio $e$ harmonia dos mais poderes politicos" (art. 98). 
era exercido pelo Conselho de Ministros, dirigido por seu Presidente, que necessitava do apoio da maioria parlamentar, tanto para a investidura quanto para a permanência em funções. E, em conseqüência, a política brasileira passou a compreender moções de desconfiança, questões de confiança, quedas de gabinete: toda a vivência, enfim, do parlamentarismo.

Críticos liberais, entretanto, denunciavam o artificialismo do sistema. Apontavam que, dada a inconfiabilidade dos resultados eleitorais, que eram realizadas sob a influência do gabinete em funções, o Imperador podia designar quem quisesse para constituir o gabinete, pois, se este náo tivesse maioria parlamentar, a eleição seguinte, apressada pela dissolução da Câmara, criaria fatalmente essa maioria.

Por outro lado, os críticos republicanos, e isto explica o abandono do sistema com a queda do Império, tinham ojeriza pelo parlamentarismo, a que se referiam pejorativamente como o "regime do falatório e da intriga" Assim, o republicanismo brasileiro era, desde a origem, presidencialista. E nisto coincidiam tanto os liberais, que viam nos Estados Unidos da América o modelo, como a forte corrente positivista que, inspirada nas lições de Comte, assumiu forte influência no Exército brasileiro nos anos 80, partidária que era da "ditadura republicana".

14. Adotado o presidencialismo na Constituição de 1891, foi ele mantido na de 1934, na de 1937 (que, na verdade, foi apenas nominal), na de 1946, como na de 1967.

Ao cair o Estado Novo, em 1945, surgiu uma significativa corrente parlamentarista, no cenário nacional, particularmente forte no Rio Grande do Sul. Esta vinculação regional tem sua explicação. Vigente a Constituição de 1891, os positivistas conquistaram o poder nesse Estado e lhe deram uma Constituição nos moldes da "ditadura republicana". A oposição gaúcha aos positivistas locais (os "castilhistas") assumiu, até por reação, a bandeira parlamentarista.

A tese parlamentarista não vingou na Constituinte, portanto, na Constituição brasileira de 1946. Entretanto, logrou impor-se na Constituição do Rio Grande do Sul, que se estabeleceu a seguir. O Supremo Tribunal Federal, todavia, declarou inconstitucional esse sistema, por entender que ele feria a 
"independência e harmonia dos poderes", que a Constituição Federal obrigava os Estados a respeitar.

Os parlamentaristas gaúchos, sob a liderança do deputado Raul Pila, desenvolveram, a partir de então, uma campanha nacional em favor do sistema. E foram ganhando valiosos apoios, graças, especialmente, às crises políticas dos anos 50. Assim, é de citar-se a adesão de Afonso Arinos, constitucionalista e parlamentar de renome, que sempre se opusera às propostas de adoção do sistema parlamentarista, quando debatidas no Congresso Nacional, como o foram, sem êxito, em 1949 e 1952.

A crise de 1961 trouxe, com a Emenda n. 4 à Constituição de 1946, a adoção do parlamentarismo. Foi um arranjo de circunstância para evitar uma guerra civil prestes a eclodir.

De fato, a eleição de 1960 dera vitória a Jânio Quadros para a Presidência da República, a João Goulart para a Vice-Presidência. Ora, ambos não pertenciam à mesma orientação política, nem contavam com o mesmo apoio (Jânio era o candidato da oposição, Goulart, da situação, e suspeito de simpatias para com o sindicalismo à moda peronista, além de ser o candidato da extremaesquerda). A sua eleição concomitante apenas fora possível em razão de serem disputadas à parte a Presidência e a Vice-Presidência e ter havido uma dissidência a enfraquecer o candidato à Vice-Presidência dos aliados de Jânio.

Desse modo, ao ocorrer a renúncia deste, em agosto de 1961, constitucionalmente o substituiria João Goulart, mas este era inaceitável para os que haviam apoiado Jânio e se consideravam representantes da maioria do povo brasileiro. Ademais, contavam eles com o apoio de forte corrente militar, radicalmente hostil ao esquerdismo de Goulart. Ora, como este contava com apoio militar, também, em nome da legalidade, depois de uma difícil negociação evitou-se o conflito armado, adotando-se o parlamentarismo. Com este sistema, Goulart "reinaria" mas não governaria...

O novo sistema, porém, teve o seu funcionamento comprometido desde o primeiro momento. Com efeito, Goulart e seus partidários, mormente os mais à esquerda, não se conformaram com a "castração" (como diziam) dos poderes do Presidente. Em conseqüência, desenvolveram uma acerba campanha contra o parlamentarismo que levou à sua revugação, num plebiscito em janeiro 
de 1963. Mas igualmente isto selou a sorte de João Goulart, que iria ser deposto pelo movimento revolucionário de 1964 , com as decorrências que se conhecem.

15. A Constituinte reuniu forte corrente parlamentarista, distribuída por muitos dos partidos que a integravam. Esta corrente logrou maioria na Comissão de Sistematização que elaborou o Projeto de Constituição. Entretanto, emendas, apoiadas pela influência do então Presidente José Sarney, foram aprovadas pelo Plenário, no primeiro turno de discussão e votação, que mantiveram o presidencialismo. Previu-se, porém, no Ato das Disposições Constitucionais Transitórias, que, em 7 de setembro de 1993, se realizará um plebiscito para que o povo escolha entre parlamentarismo e presidencialismo (art. $2^{9}$ ), plebiscito este agora antecipado para 21 de abril de 1993.

16. De acordo com a Constituição em vigor, cabe ao Presidente da República o Poder Executivo, independente do Poder Legislativo e do Poder Judiciário.

Ele o exercerá, como diz o art. 76 da Constituição, com o auxílio dos Ministros de Estado. Estes ele livremente escolhe e exonera.

É eleito pelo voto popular direto, pelo princípio majoritário. Eventualmente, em dois turnos de votação, já que no primeiro só se elegerá quem obtiver a maioria absoluta dos votos (não computados os nulos e os em branco). Caso isto não ocorra, haverá um segundo turno disputado, apenas, pelos dois mais votados do primeiro.

Tem um mandato de cinco anos, que somente poderá ser extinto em caso de crime de responsabilidade, por meio de impeachment.

17. Cumpre ao Presidente da República todos os papéis que Corwin assinala serem desempenhados pelo Presidente da República dos Estados Unidos, embora com algumas qualificaçōes. ${ }^{12}$ Ele é o "administrative chief", o "chief executive", o "organ of foreign relations", o "commander-in-chief" e o "legislative leader".

12. Edward S. Corwin, The president: office and powers, $4^{\mathrm{a}}$ ed., New York, New York Univ. Press, 1964. 
Como "administrative chief", ele tem nas mãos a "direção superior da administração federal", nomeia e exonera os Ministros de Estado, provê e extingue os cargos públicos federais, etc. (art. 84).

Como "chief executive", regulamenta as leis, decreta o estado de defesa e o estado de sítio, decreta e executa a intervenção federal, concede indulto e comuta penas, etc. (art. 84).

Como "organ of foreign relations", mantém relações com Estados estrangeiros e acredita seus representantes diplomáticos, celebra tratados, convenções e atos internacionais, declara a guerra e celebra a paz, etc. (art. 84).

Como "commander-in-chief", exerce o comando supremo das Forças Armadas, decreta a mobilização nacional, promove os oficiais-generais, nomeia-os para os cargos que thes são privativos, etc. (art. 84).

Como "legislative leader", exerce a iniciativa legislativa, veta projetos aprovados, sanciona-os, promulga-os e publica-os, etc. (art. 84). Ademais, possui o poder de editar, sem a necessidade de autorização do Legislativo, "medidas provisórias com força de lei" (art. 62) ${ }^{13}$ e com autorização deste "leis delegadas" (art. 68). É, assim, o Presidente da República, no Brasil, um legislador, conquanto excepcional, segundo a letra da Constituição.

Enfim, cumpre não olvidar que o Presidente nomeia os integrantes do Supremo Tribunal Federal, dos Tribunais Superiores e outros magistrados, o Procurador-Geral da República e o Advogado-Geral da União, membros do Tribunal de Contas da União, o presidente e os diretores do Banco Central, etc. (art. 84).

De modo geral, já possuía ele esses poderes no direito anterior. Comparativamente com este, perdeu ele um pouco de sua força, juridicamente falando. De fato, depende de aprovação prévia por parte do Senado a nomeação de muitas das autoridades que ele escolhe; algumas atribuições administrativas estão agora sujeitas à apreciação do Congresso Nacional, como atos de concessão e renovação de concessão de emissoras de rádio e televisão, atos relativos a atividades nucleares, etc.

13. O texto da norma constitucional sobre as medidas provisórias acha-se no item 27 deste trabalho. 
No exercício de algumas funções, tem de ouvir a opinião de um ou mesmo dos dois Conselhos que a Constituição criou: o Conselho da República (art. 90) e o Conselho de Defesa Nacional (art. 91). O primeiro quanto a questões relevantes para a estabilidade das instituições; este, para os assuntos relacionados com a soberania nacional e a defesa do Estado democrático.

18. Entretanto, a força política do Presidente da República muito ganha com a eleição direta, ainda mais num sistema em que fatalmente ele poderá invocar a escolha pela maioria absoluta do povo brasileiro.

$\mathrm{Na}$ realidade, a eleição presidencial direta foi denunciada, vigente a Constituição de 1946, como um dos males do presidencialismo. Afonso Arinos converteu-se ao parlamentarismo, apontando a eleição presidencial direta como um "plebiscito entre dois demagogos", plebiscito este que seria fatalmente vencido por "aquele que mais esperanças privatistas despertou nos indivíduos, classes $e$ grupos. Aquele que mais prometeu às coletividades e nāo à coletividade, aquele que mais mentiu a seçōes separadas do povo e menos falou a dura verdade ao povo em conjunto". E, com pessimismo, concluiu Arinos: "Isso cada vez será pior". ${ }^{14}$

Na verdade, a exacerbação do poder presidencial, que leva muitos a preferirem o parlamentarismo, tem além dessa causa política, algumas outras.

Uma é a fragilidade do sistema partidário. Não tem o País verdadeiros partidos, embora sejam eles, hoje, mais de trinta: isto é, partidos com um programa, ainda que vago, um mínimo de disciplina e coerência. Conseqüentemente, o Presidente da República faz, no Congresso, com toda a facilidade, a sua maioria, em geral por meio das benesses que pode distribuir. Ora, à falta de tal sistema partidário, não se vê como um sistema parlamentarista possa sustentar-se. Ao invés, fácil é predizer que será ele instável e impotente.

Outra é a falta de prestígio do Legislativo que, assim, não lhe pode servir de contrapeso. E a ela não socorre o prestígio do Judiciário que, embora o tenha maior, longe está de contar com o respeito de que goza a Suprema Corte dos Estados Unidos.

14. Afonso Arinos de Melo Franco e Raul Pila, Presidencialismo ou parlamentarismo?, Rio de Janeiro, José Olímpio, 1958, p. XXIII. 
O desprestígio do Legislativo decorre, entre outros fatores, do fato de que ele não tem dado conta de sua tarefa essencial: a de legislar. Por isso, já a Constituição anterior previa uma legiferação pelo Executivo, com o decreto-lei. E a atual, conforme já se apontou, prevê as "medidas provisórias com força de lei", que efetivam em mãos do Presidente a indesejável concentração do Poder Executivo com o Poder Legislativo. Nega-se com isto a grande virtude da separação dos poderes, ainda que formalmente a Constituição a ela adira.

III. A ordem econômica.

19. Nenhum tema provocou na Constituição um confronto tâo aceso quanto a definição da ordem econômica. A corrente de esquerda, estatizante, socializante, até marxizante, logrou êxito nas primeiras etapas, inclusive no estabelecimento do Projeto; entretanto, a corrente liberal reagiu durante a discussão deste e logrou fazer aprovar várias emendas que alteraram, em substância, o texto proposto. Deste confronto resultaram, pela necessidade de acordos e transigências, ambigüidades e dificuldades na interpretação da ordem econômica na Constituição em vigor. Inclusive, com a formação entre os juristas, como se verá, de pelo menos três linhas de opinião divergentes entre si.

Vale observar, ademais, que o Texto vigente contém uma verdadeira "constituição econômica". De fato, ela regula expressamente os quatro aspectos fundamentais que a doutrina considera essenciais a esse respeito:

a. o estabelecimento do tipo de organização econômica, que repercute na

b. delimitação entre o campo da iniciativa privada e o da iniciativa pública; bem como

c. a determinação do regime jurídico dos fatores de produção; tudo encimado pela

econômica. ${ }^{15}$

d. definição da finalidade $e$ dos princípios gerais da vida

15. V. meus estudos Lineamentos de uma Constituição econômica e Democracia política e democracia econômica, publicados em Idéias para a nova Constituição brasileira, São Paulo, Saraiva, 1987, p. 119 e ss. e p. 135 e ss., respectivamente. 
20. Quanto a este último ponto, é fundamental o art. 170 da Constituição.

No caput deste artigo, é indicada a finalidade da ordem econômica: "assegurar a todos existência digna". Reflete-se aqui a doutrina da Igreja, que, seguindo Santo Tomás de Aquino, vê na "vida humana digna" a essência do bem comum. Há, é certo, neste passo, um eco do art. 151 da Constituição de Weimar, por intermédio do art. 115 da Constituição brasileira de 1934. Significativo é contrapor-se essa finalidade à que atribuía à ordem econômica o art. 160, caput, da Lei Magna anterior: "realizar o desenvolvimento nacional e a justiça social".

Ainda no caput do art. 170 afirmam-se como fundamentos da ordem econômica "a valorização do trabalho humano" e a "livre iniciativa" $\mathrm{Na}$ verdade, estavam ambos presentes no direito anterior. Por outro lado, esses dois pontos já estavam sublinhados no próprio art. $1^{\mathrm{O}}$ da Constituição, que inscreve entre os fundamentos do Estado Brasileiro "os valores sociais do trabalho e da live iniciativa" (inciso IV).

Por outro lado, o art. 170 destaca vários princípios que deverão orientar a atividade econômica: a soberania nacional (I), reflexo de sua inspiração nacionalista; a propriedade privada e a livre concorrência, incluídos pela ala liberal da Constituinte (II e IV); função social da propriedade, referência que desde 1934 está no direito constitucional brasileiro por força da dupla influência da doutrina social da Igreja e do positivismo (III); a defesa do consumidor e a defesa do meio ambiente (V e VI), temas em voga no mundo inteiro; a redução das desigualdades regionais e sociais e a busca do pleno emprego (VII e VIII), temas caros à linha socializante; tratamento favorecido para as empresas brasileiras de capital nacional de pequeno porte (IX), que espelha a angústia dos pequenos empresários em face da concentração econômica produzida pelo desenvolvimento capitalista. Enfim, num parágrafo único, se ajuntou o princípio de que toda atividade econômica e livre, independentemente de autorização por parte do Poder Público - essência da livre iniciativa mas ressalvados os casos previstos em lei, o que obviamente esvazia o preceito.

Vê-se bem dessa congérie de princípios o caráter compósito da inspiração do constituinte, reflexo da divisão ideológica presente na Assembléia. 
21. A definição do tipo de organização econômica é o cerne de uma Constituição econômica. É o ponto que traduz a opção entre uma economia descentralizada e uma economia centralizada. Ou seja, entre uma economia de mercado e uma economia comandada de um centro de Poder. ${ }^{16}$

O Anteprojeto elaborado pela Comissão de Sistematização da Constituinte continha uma definição do tipo de economia, que equivalia a caracterizá-la como centralizada. Era o que se via no art. 310: "Como agente normativo e regulador da atividade econômica, o Estado exercerá as funções de controle, fiscalização e planejamento, que será imperativo para o setor público e indicativo para o setor privado". E este texto foi repetido pelo art. 203 do Projeto.

$\mathrm{O}$ termo controle na linguagem jurídica brasileira é ambíguo. De fato, ele provém, conforme a inspiração de quem o emprega, ou do francês "contrôle", que traduzido para o vernáculo seria "fiscalização", ou do inglês "control", que antes significa "poder sobre", "dominação". Entretanto, controle num texto que fala também em fiscalização somente pode significar "dominação", e era isso o que decorria do texto do Anteprojeto e do Projeto. E isto era bem o que queria o PT (Partido dos Trabalhadores), agremiação de esquerda radical, responsável pela proposta.

Uma emenda, proposta pelo chamado Centrão, aprovada no primeiro turno de discussão e votação, eliminou a menção a controle e acrescentou a referência a "incentivo". Ficou assim o texto, do que é o art. 174 da Constituição: "Como agente normativo e regulador da atividade econômica, o Estado exercerá, na forma da lei, as funçôes de fiscalização, incentivo e planejamento, sendo este determinante para o setor público e indicativo para o setor privado".

Ora, esta redação ensejou uma forte controvérsia, ainda não extinta.

Alguns dão-lhe uma interpretação ultraliberal, entendendo que o Estado não poderia senão desempenhar as funções estritamente entendidas de "fiscalização, incentivo e planejamento". Ademais, invocavam em apoio desta

16. V. a este respeito, além dos trabalhos citados na nota anterior, Raymond Barre, Économie politique, $2^{\mathrm{a}}$ ed., Paris, P.U.F., 1957, t. 1, p. 185 e ss. 
exegese os princípios de livre iniciativa, livre concorrência, de que fala o art. 170.17

Outros, em posição oposta, continuam a ler o preceito tal qual ele estava no Projeto, como se ele não houvesse sido alterado. Enfatizam, para tanto, o papel do Estado de "agente regulador" da atividade econômica. ${ }^{18}$

Enfim, uma terceira corrente, moderada, entende que o texto referido, se exclui uma economia centralizada, deixa largo campo para a intervenção do Estado, quer de índole normativa, quer de índole regulatória. E nesta atuação interventiva pode ele fiscalizar, incentivar e planejar a atividade econômica. $^{19}$

22. No tocante ao relacionamento entre iniciativa privada e iniciativa pública, cumpre lembrar que a Constituição anterior, no art. 170, afirmava a primazia da iniciativa privada na exploração de atividade econômica e punha como excepcional o desempenho de atividade dessa natureza por parte do Estado. Ela só caberia "em caráter suplementar da iniciativa privada". Não obstante isto, sob essa Constituição é que mais cresceu a atuação direta do Estado na atividade econômica, com a multiplicação de empresas ditas "estatais", quase todas deficitárias, porque ineficientes e sobrecarregadas de empregados desnecessários, admitidos por motivos eleitorais.

$\mathrm{Na}$ Constituição vigente, o art. 173 põe ainda como subsidiária a atividade direta do Estado no campo econômico, embora o faça de modo menos enfático. Entretanto, admite-a quando "necessária aos imperativos da segurança nacional ou a relevante interesse coletivo, conforme definidos em lei" Fácil é ver, portanto, que uma decisão política, tomada por meio de lei, pode estender a

17. A esta primeira corrente pertence o Professor Miguel Reale. Fazendo tábua rasa do Anteprojeto e do Projeto (pois, a lei é mais sábia do que o legislador), considera ele a Constituição de 1988 de orientação essencialmente liberal. Assim, esta proibiria formas de intervenção na economia, como os congelamentos e tabelamentos de preços, que haviam sido estabelecidos (e que voltaram a ser estabelecidos depois de vigente a nova Constituição).

18. V. José Afonso da Silva, ob. cit., p. 674.

19. A esta corrente filio-me eu, conforme está em meu livro Direito constitucional econômico, Sāo Paulo, Saraiva, 1990. Os tribunais, em face do Plano Collor, parecem dar-lhe razāo. 
atuação do Estado no domínio econômico, sob a invocação de "relevante interesse coletivo"

23. O regime jurídico, básico, do trabalho está fixado num capítulo dedicado aos "Direitos Sociais", que se inclui no Título relativo aos "Direitos $e$ Garantias Fundamentais".

Enuncia o art. $6^{0}$ da Constituição, desde logo, esses direitos sociais. São eles o direito à educação, à saúde, ao trabalho, ao lazer, à segurança, à previdência social, à proteção à maternidade e à infância, a assistência aos desamparados.

A seu turno, o art. $7^{\circ}$ aponta, exemplificativamente, os direitos do trabalhador. São estes entre outros: garantia no emprego, participação nos lucros, duração máxima do trabalho semanal fixada em quarenta e quatro horas, jornada não excedente a oito horas, repouso semanal remunerado, férias anuais remuneradas, licença-maternidade, licença-paternidade, aviso prévio, aposentadoria, etc.

Já o art. 8o declara livre a associação profissional ou sindical, vedando a ingerência do Estado, quer na sua organização, quer no seu funcionamento.

Por sua vez, o art. $9^{\circ}$ assegura o direito de greve, "competindo aos trabalhadores decidir sobre a oportunidade de exercê-lo e sobre os interesses que devam por meio dele defender". Isto configura uma grande ampliação do seu alcance, já que no direito anterior era vedada a greve nas "atividades essenciais, definidas em lei". São, todavia, sancionados os abusos cometidos no seu exercício.

24. Não prevê a Constituição normas especiais referentes ao capital, nem a "nacionalizações", "estatizações" ou "privatizações"

Assim, deve-se admitir que o regime do capital é o da propriedade em geral.

Esta é garantida, salvo desapropriação por necessidade ou utilidade pública, ou interesse social, sempre mediante prévia e justa indenização em dinheiro. A desapropriação de bens imóveis para fins de reforma agrária ou de reforma urbana pode, é certo, ser paga em títulos especiais.

A Constituição vigente aborda, porém, a questão da nacionalidade da empresa. Segundo ela, é empresa brasileira toda aquela que for "constituída 
sob as leis brasileiras e que tenha sua sede e administraçāo no País" (art. 171, I). Reconhece como empresa brasileira de capital nacional somente "aquela cujo controle efetivo esteja em caráter permanente sob a titularidade direta ou indireta de pessoas físicas domiciliadas e residentes no País ou de entidades de direito público interno, entendendo-se por controle efetivo da empresa a titularidade da maioria de seu capital votante e exercício, de fato e de direito, do poder decisório para gerir suas atividades" (art. 171, II). Assim, a contrario sensu, pode haver empresa brasileira de capital estrangeiro.

A distinção que é feita entre as empresas brasileiras em função de seu capital ser ou não nacional, tem por motivo ensejar um favorecimento à de capital nacional. Este favorecimento aparece nos $\S \S 1^{\mathrm{o}}$ e $2^{\mathrm{o}}$ do art. 171. O primeiro o limita a atividades "estratégicas para a defesa nacional ou imprescindiveis ao desenvolvimento do País", mormente ao "desenvolvimento tecnológico nacional", e não admite senão a concessão de benefícios temporários. O segundo dá "tratamento preferencial, nos termos da lei, à empresa brasileira de capital nacional"

Acrescente-se que o capital estrangeiro é excluído de vários setores: pesquisa e lavra de recursos minerais, aproveitamento de potenciais de energia elétrica (art. 176); pesquisa e lavra de jazidas de petróleo e gás natural, transporte marítimo de petróleo bruto, pesquisa, lavra e enriquecimento bem como reprocessamento, industrialização e comércio de minérios e minerais nucleares (art. 177); e navegação de cabotagem (art. 178).

\section{A prática até agora.}

25. Cabem, à guisa de conclusão, algumas observações sob sua prática.

A primeira é a de que ela permanece em boa parte ineficaz, portanto, inefetiva. $\mathrm{O}$ constituinte, que se tornou membro do Congresso, finda a obra constitucional (cujo mandato acaba de terminar), parece haver-se desinteressado de dar seguimento ao trabalho, mormente complementar às novidades que adotou, regulamentando-as.

De fato, ainda não foi regulamentada a esmagadora maioria das normas não-auto-executáveis que ela contém em profusão. Assim, somente se aplicam, na realidade, as normas auto-executáveis da Constituição. Isto significa 
que a ordem política é regida pelo novo regime (praticamente igual ao anterior depois da Emenda n. 25/85), que a ordem econômica o é em parte, mas que a ordem social continua, quase toda, no plano da promessa.

Razão para isto parece decorrer do fato de que essa ordem social, generosa nos benefícios, não encontra no momento de crise financeira que o País vive, condições de implementação.

Ademais, os mecanismos judiciais de vinculação do legislador, o mandado de injunção e a ação de inconstitucionalidade por omissão, não produziram ainda qualquer fruto, digno de menção.

26.

Por outro lado, a Presidência Collor de Mello, iniciada em 15 de março de 1990, vem mostrando em toda a sua plenitude o presidencialismo exacerbado que se pretendia coibir.

Apoiado na maioria absoluta obtida no segundo turno do pleito, em dezembro de 1989, o novo Presidente desencadeou um programa nunca visto no País de medidas radicais, com o objetivo de estancar a inflação, principalmente. Basta observar que das contas correntes bancárias ou das contas de poupança, seja de particulares, seja de empresas, congelou oitenta por cento do saldo, desde que superior a $\mathrm{Cr} \$ 50.000,00$. Igualmente, congelou outros haveres aplicados em fundos e títulos. E, para evitar o crivo judicial imediato, suspendeu a possibilidade de concessão de medidas liminares contra o Plano.

Tudo isto foi feito sem consulta ao Congresso Nacional, cuja maioria, aliás, não o apoiou na eleição. Este, porém, não reagiu senão muito moderadamente e de modo especialmente verbal contra as medidas. Aprovou todas as medidas básicas do Plano, rejeitou só um dos atos normativos que a ele se ligam, emendou outros poucos, permitiu a reedição dos que não quis converter em lei. Frágil contrapeso tem sido ele.

Quanto ao Judiciário, este, embora com o vagar costumeiro, vem corrigindo tais desvios, impondo o respeito à Lei Magna. 
27. O Presidente da República não poderia fazer o que faz se não contasse com um instrumento de legiferação que, no seu efeito imediato, prescinde da concordância do Legislativo: as medidas provisórias. ${ }^{20}$

Vale reproduzir a norma constitucional que o autoriza a editá-las. Trata-se do art. 62:

"Em caso de relevância e ungência, o Presidente da República poderá adotar medidas provisórias, com força de lei, devendo submetê-las de imediato ao Congresso Nacional, que, estando em recesso, será convocado extraordinariamente para se reunir no prazo de cinco dias.

Parágrafo único: As medidas provisórias perderão eficácia, desde a ediçāo, se não forem convertidas em lei no prazo de trinta dias, a partir de sua publicação, devendo o Congresso Nacional disciplinar as relações jurídicas delas decorrentes".

Deflui do texto que o Presidente legisla, embora provisoriamente, sobre qualquer matéria. As normas que assim edita são imediatamente eficazes, portanto, imediatamente aplicáveis. É certo que perdem eficácia no prazo de trinta dias se até lá não tiverem sido acolhidas pelo Legislativo, ou antes mesmo, se por ele rejeitadas.

Entretanto, a prática já mostra que o Legislativo, de modo geral, não ousa rejeitar as medidas provisórias (só o fez uma vez e por acidente). Hesita em subscrevê-las, de modo que é freqüente escoar o prazo de trinta dias sem sua manifestação. Isto redundaria na perda de eficácia das normas, contudo já se aceitou a praxe da renovação das medidas provisórias, por ato presidencial. $\mathrm{O}$ que significa que elas perduram vigentes sem a aprovação do Congresso Nacional.

A inconstitucionalidade dessa praxe foi levantada perante o Supremo Tribunal Federal. Este, porém, só acolheu, e numa decisão que não é

20. V. sobre as medidas provisórias meu artigo "As medidas provisórias com força de lei", em Repertório IOB de Jurisprudência, n. 5, p. 89 e ss, $1^{\text {a }}$ quinz. mar. 1989. 
definitiva, essa tese num caso único, em que se renovava medida provisória rejeitada pelo Congresso. De seu posicionamento parece possível inferir que ele admite a renovação de medida provisória não rejeitada.

\section{Observações finais.}

28. No momento em que se concluem estas observações, está em curso grave crise político-institucional. Com efeito, em razão de elementos colhidos por uma Comissão Parlamentar de Inquérito, está pendente de decisão, na Câmara dos Deputados, pedido de autorização para submeter o Presidente da República a processo e julgamento, perante o Senado, por crime de responsabilidade.

No plano jurídico, essa postulação encontra graves dificuldades em virtude de o Congresso Nacional não haver ainda estabelecido a lei de complementação reclamada pelo art. 85, parágrafo único, lei esta consentânea com as modificaçóes que imprimiu ao processo dos crimes de responsabilidade a Constituição em vigor.

Por outro lado, mais uma vez se põe a questão da exeqüibilidade do impeachment no Estado contemporâneo. E a busca de sistema alternativo, de acordo com as peculiaridades do presidencialismo.

Tudo isto, ademais, fortalece a proposta parlamentarista, alternativa mais uma vez alvitrada nos cenáculos políticos. 